\title{
Lending Relationships and the Collateral Channel
}

\author{
Gareth Anderson*† Saleem Bahaj ${ }^{\dagger} \quad$ Matthieu Chavaz ${ }^{\dagger}$ \\ Angus Foulis ${ }^{\dagger} \quad$ Gabor Pinter ${ }^{\dagger}$
}

May 15, 2018

\begin{abstract}
This paper shows that lending relationships insulate corporate investment from shocks to collateral values. We construct a novel database covering the banking relationships of UK firms, as well as those of their board members and executives. We find that the sensitivity of corporate investment to shocks to real estate collateral value is halved when the length of the bank-firm relationship increases from the 25 th to the 75th percentile. This effect is substantially reduced for firms whose executives have a personal mortgage relationship with their firm's bank. Our findings provide support for theories where collateral and private information are substitutes in mitigating credit frictions over the cycle.
\end{abstract}

*University of Oxford

†Bank of England. Contact author: matthieu.chavaz@bankofengland.co.uk. We thank Sumit Agarwal, Allen Berger, Steve Bond, Raj Iyer, Farzad Saidi, Hirofumi Uchida, Greg Udell, as well as participants at Bank of England, Chicago Financial Institutions conference, Econometric Society winter meeting, and Royal Economic Society meetings for useful comments. This paper contains the views of the authors and not necessarily those of the Bank of England, the MPC, the FPC or the PRC. 


\section{Introduction}

Swings in collateral prices can generate booms and busts in corporate investment (Gan, 2007; Chaney, Sraer, and Thesmar, 2012). This collateral channel is consistent with theories where collateral mitigates contracting frictions and thus increases firms' borrowing capacity in a procyclical way (Bernanke and Gertler, 1989; Kiyotaki and Moore, 1997).

However, collateral is only one of several potential determinants of credit frictions over the cycle. An extensive corporate finance literature shows that agency problems can be mitigated by intense firm-bank lending relationships. And influential macroeconomic theories stress that credit cycles arise from the interaction between fluctuations in collateral values and information issues (Gertler, 1992; Holmstrom and Tirole, 1997).

This paper seeks to reconcile these literatures. Our key question is: do strong lending relationships between banks and corporates and their executives amplify or moderate the link between collateral and investment?

In addition to informing policies aiming to curb credit cycles, this question is motivated by conflicting theoretical clues. Strong lending relationships could mitigate the collateral channel if relationships act as a substitute for collateral - for instance because they both help to overcome informational asymmetries in lending contracts (Boot, 2000). But strong relationships could accelerate the collateral channel if relationships and collateral are complements - for instance if private information helps lenders to monitor collateral (Rajan and Winton, 1995) or extract rents from borrowers (Sharpe, 1990; Rajan, 1992).

Our results provide clear support for the first hypothesis: the longer lending relationships between banks and both corporates and their executives, the slower the "accelerator" whereby shocks to the value of corporate collateral affect corporate investment dynamics. 
We use a panel dataset of UK firms covering the 2002-2013 period. The data and setup have two unique features. First, the panel covers the entire universe of UK companies, whereas datasets available for other countries typically focus on either SMEs or publicly listed firms. This allows us to test whether the importance of lending relationships and collateral varies across firm types and size, as predicted by theory. This is particularly useful in the UK context, where both bank-based and market-based corporate finance are highly developed. Second, the data reports information on the banking relationships of the firm and the personal mortgage relationships of each of its individual directors. This allows us to explore the importance of both types of relationships. The UK is a particularly rich laboratory in this context, with around $40 \%$ of UK SMEs reporting debt secured by residential real estate - that is, the own houses of their director(s).

Our main test investigates how lending relationship intensity affects the response of corporate investment to shocks to the value of real estate collateral. To mitigate the endogeneity of collateral holdings, we follow Benmelech and Bergman (2009) and Chaney, Sraer, and Thesmar (2012) and use a proxy which interacts (i) the initial value of corporate collateral at the start of the sample, and (ii) plausibly exogenous yearly changes in regional land prices across 204 local authorities in England, Scotland, and Wales. We then interact this proxy with a measure of relationship intensity to test the conflicting hypotheses outlined above.

The granularity of our data allows us to address a number of related empirical challenges with fixed effects. Because initial collateral holdings might be correlated with unobserved firm characteristics, our baseline specification includes firm fixed effects. Real estate price shocks could also affect corporate investment through demand-side channels, such as local investment opportunities (Giroud and Mueller, 2016) or agglomeration effects (Dougal, Par- 
sons, and Titman, 2015). We mitigate these channels by including region-year fixed effects in our regressions. In contrast to several existing studies of the collateral channel, we observe the identity of both firms and their lenders. Therefore, we can additionally include bank-year fixed effects; this allows us to control for the possible impact of real estate prices on corporate investment though its effect on banks' lending capacity (Gan, 2007; Flannery and Lin, 2016). Because unobserved determinants of both collateral and relationship decisions and investment dynamics could still bias our results, we instrument for local real estate prices using the geography-based instrument of Saiz (2010) adapted for the UK as a robustness check.

Our key results are the following. Consistent with Chaney, Sraer, and Thesmar (2012), we find that increasing collateral values are associated with higher corporate investment: a $£ 1$ increase in the value of corporate collateral increases investment by around $£ 0.04$. But we find that this effect is significantly reduced for firms with longer banking relationships. A firm with a 75 th percentile relationship length (15.4 years) increases investment by around $50 \%$ less than a firm with a 25 th percentile relationship length (4.2 years) when collateral values increase. Overall, this finding is consistent with the notion that lending relationships dampen the effect of collateral value on borrowing constraints, as predicted by models where collateral and private information are substitutes (Holmstrom and Tirole, 1997; Boot, 2000).

This interpretation raises a number of further identification issues. First, relationship length and collateral holding decisions might be correlated with confounding determinants of corporate investment, such as firm size (Gertler and Gilchrist, 1994; Adelino, Schoar, and Severino, 2015), age (Siemer, 2014) or credit score (Boot, Thakor, and Udell, 1991). We show that introducing additional controls for these factors and their interaction with collat- 
eral value does not change our results. Second, relationship length and collateral usage could also be affected by bank characteristics (Schwert, 2018); however, we find that controlling for lender size or financial strength does not affect our conclusions. Finally, our key result remains similar when we consider manuacturing firms only; this eliminates firms in the nontradable and real estate sectors, whose demand might be more affected by local economic conditions and asset prices. Because manufacturing firms are likely to export their products out of their home region, this result provides further comfort that our results are not driven by demand-side effects (Adelino, Schoar, and Severino, 2015).

We document several results providing additional support for our interpretation of the results. First, we run the baseline regression using short-term and long-term corporate borrowing as the dependent variable. Consistent with theory emphasising frictions in long-term debt contracts, we find that lending relationships only mitigate the response of long-term borrowing to changes in collateral value. Second, we show that lending relationships only significantly mitigate the collateral channel for private firms. This is consistent with the notion that publicly listed firms circumvent bank lending and collateral constraints by borrowing from capital markets or face smaller informational constraints.

The last part of the paper investigates whether personal lending relationships between banks and company executives affect corporate investment above and beyond corporate lending relationships. Our dataset has two unique features compared to the existing studies (Karolyi, 2018). First, we observe the identity of both executives and shareholders of all UK private and public firms. Second, we have information on the personal mortgage relationship of these individuals. Our results suggest that corporate relationships insulate investment from collateral value shocks to a lesser extent for firms whose directors also have 
personal relationships with the same bank; in other words, personal lending relationships act as a substitute for corporate relationships.

Contributions To our knowledge, our paper is the first to show that banking relationships mitigate the impact of collateral values on corporate investment.

The link between swings in collateral values and corporate investment is well established; ${ }^{1}$ but the role of lending relationships within these dynamics remains unexplored. Conversely, lending relationships are known to support lending during downturns; ${ }^{2}$ but it is less clear whether this affects real outcomes, and what role collateral plays in this context. Several microeconomic studies emphasise the link between collateral and lending relationships, but not its effect on corporate investment dynamics. ${ }^{3}$

Our findings add to evidence that cyclical fluctuations in house prices have more powerful effects on the activity of small and/or young firms. ${ }^{4}$ We share with these papers the notion that collateral constraints are more binding for firms subject to otherwise more severe financial frictions. But we show that these frictions are mitigated by long-term lending relationships, and that this mechanism is distinct from a size or age effect.

Finally, our paper adds to a nascent literature on lending relationships between banks and individuals within firms. Karolyi (2018) finds that relationships between executives and banks mitigate the impact of recessions on corporate investment. Our data allow us

\footnotetext{
${ }^{1}$ Gan (2007); Chaney, Sraer, and Thesmar (2012); Cvijanovic (2014); Kleiner (2015); Ersahin and Irani (2015); Bahaj, Foulis, and Pinter (2016).

${ }^{2}$ Jimenez, Ongena, Peydro, and Saurina (2012); Sette and Gobbi (2015); DeYoung, Gron, Torna, and Winton (2015); Bolton, Freixas, and Gambacorta (2016); Banerjee, Gambacorta, and Sette (2017); Beck, Degryse, De Haas, and Van Horen (2018).

${ }^{3}$ Jimenez, Salas, and Saurina (2006); Berger, Frame, and Ioannidou (2011). The findings of this literature are inconclusive. For instance, Berger and Udell (1995) find that firms with long relationships post less collateral, while Ono and Uesugi (2009) and Cerqueiro, Ongena, and Roszbach (2016) find that bank monitoring increases with corporate collateral usage and value.

${ }^{4}$ Fort, Haltiwanger, Jarmin, and Miranda (2013); Siemer (2014); Adelino, Schoar, and Severino (2015); Banerjee and Blickle (2016).
} 
to not only observe the identity of company executives and shareholders, but also their private mortgage relationships. Our findings suggest that these relationships affect corporate investment dynamics in both good and bad times.

\section{Testable Hypotheses and Empirical Strategy}

Financial intermediation theory offers two conflicting predictions about the role of banking relationships for the collateral channel. ${ }^{5}$

A first strand of theories suggests that relationships and collateral play a similar role in overcoming adverse selection and moral hazard issues in debt contracts. Relationships mitigate the adverse selection problem to the extent that they provide lenders with private information about a borrower's default risk (Boot, 2000); relationships also reduce moral hazard by reducing monitoring costs after a loan is granted. Similarily, collateral helps lenders to screen otherwise similar prospective borrowers ex ante (Bester, 1985; Besanko and Thakor, 1987), and monitor borrowers ex post (Boot, Thakor, and Udell, 1991).

If they are a substitute for collateral, stronger banking relationships might dampen the link between firm collateral and firm investment. For example, lenders can require less (more) collateral from firms they are able to monitor more (less) intensively (Holmstrom and Tirole, 1997; Manove, Padilla, and Pagano, 2001). Alternatively, lenders might be willing to abstract from crisis-time drops in the collateral value of firms with which they have ongoing, profitable relationships (Sette and Gobbi, 2015; Bolton, Freixas, and Gambacorta, 2016; Jiangli, Unal,

\footnotetext{
${ }^{5}$ Collateral and banking relationships can affect corporate investment under three conditions. Firstly, firms' cash inflows should be imperfectly correlated with their investment opportunities, thereby giving the firm a reason to seek external finance (Froot, Scharfstein, and Stein, 1993). Secondly, the firm should face frictions in accessing external finance. Thirdly, collateral and/or banking relationships should act to reduce these frictions (Holmstrom and Tirole, 1997).
} 
and Yom, 2008). In return for this bad-time "insurance" lenders may be less willing to extend more credit when collateral values rise during booms. Summing up:

Hypothesis 1 If collateral and lending relationships are substitutes, longer relationships should dampen the link between collateral and investment.

Another hypothesis is that collateral and banking relationships are complements, in which case stronger relationships could amplify the link between collateral and investment. For instance, collateral could increase lenders' incentive to monitor borrowers (Rajan and Winton, 1995), or lower the cost of doing so. Alternatively, collateral might help reducing lenders' inclination to extract rents from ("hold up") firms with which they have long-standing relationships (Sharpe, 1990; Rajan, 1992; Xu, Wang, and Rixtel, 2015). Summing up:

Hypothesis 2 If collateral and banking relationships are complements, longer relationships should amplify the link between collateral and investment.

\subsection{Empirical Specification}

Given these conflicting theories, this paper tests how lending relationships affect the response of corporate investment to shocks to real-estate collateral values. The baseline empirical specification is:

$$
\begin{aligned}
\text { Investment }_{i, t}= & \alpha_{i}+\delta_{j, t}+\mu_{k, t}+\phi \cdot \text { Firm Controls }_{i, t} \\
& +\beta \cdot \text { Collateral }_{i, t}+\kappa \cdot \text { Relationship Lengt }_{i, t} \\
& +\delta \cdot \text { Collateral }_{i, t} \times \text { Relationship Lengt }_{i, t}+\varepsilon_{i, t}
\end{aligned}
$$

where: 
$k$ at time $t$

$\alpha_{i}$ is a firm fixed effect is a region-time fixed effect

$\mu_{k, t}$ is a bank combination-time fixed effect

Firm Controls $s_{i, t} \quad$ are various controls for firm $i$

Collateral $_{i, t} \quad$ measures the value of corporate collateral

Relationship Length ${ }_{i, t}$ measures the average length of relationship between firm $i$ and its banks

In Equation 2.1, the coefficient $\beta$ measures the direct strength of the corporate collateral channel. The coefficient of interest is $\delta$, which measures the impact of Relationship Length on the collateral channel. A negative $\delta$ would imply that the collateral channel is weaker for firms which have longer relationships with their banks.

Following Chaney, Sraer, and Thesmar (2012), we identify the causal effect of the collateral channel by combining two sources of variation in real estate collateral values. Within regions, the collateral channel is identified by exploiting differences in the initial holdings of collateral. Across regions, we exploit differences in the evolution of real estate prices, as described in detail below.

The fixed effects included in Equation 2.1 address three distinct identification channels. Firm fixed effects $\left(\alpha_{i}\right)$ capture unobserved, time-invariant characteristics that could determine collateral and relationship decisions and investment dynamics; region-time fixed effects $\left(\delta_{j, t}\right)$ control for unobserved region-specific macroeconomic conditions which could affect 
corporate investment through demand-side channels; finally, bank-combination-time fixed effects $\left(\mu_{k, t}\right)$ control for the potential impact of real estate prices on banks' balance sheets and credit supply capacity (Gan, 2007). ${ }^{6}$ Our choice of firm-level controls is guided by existing literature, where our data permits it. Following the firm investment literature, (e.g. Hubbard (1998)), we include measures of cash flow as controls. In particular, we include firms' profit margin and cash ratio. We also include other correlates of collateral as controls, in particular firm age (Rajan, 1992; Bolton and Freixas, 2000) and credit score (Berger and Udell, 1995; Brick and Palia, 2007).

\section{Data, Sample, and Summary Statistics}

\subsection{Data Sources}

Corporates Our main source of information on UK companies is the Financial Analysis Made Easy (FAME) dataset, provided by Bureau Van Dijk. FAME reports financial data for all incorporated UK companies registered at Companies House; the dataset does not cover partnerships or sole proprietorships.

FAME reports data on bank-firm relationships, corporate collateral, corporate activity and corporate financing, directors' identities and addresses, as well as the postcode of each firm's trading addresses, date of incorporation, and industrial sector (4 digit SIC code). This allows us to identify the region(s) and sector within which a firm operates.

One limitation of FAME is that the reporting requirements differ by company size; only

\footnotetext{
${ }^{6}$ Fixed effects are based on the combination of banks a firm has a relationship with. For example, a firm which banks with "Bank A" and "Bank B" will have the same bank combination fixed effect as another firm which banks with "Bank A" and "Bank B". The fixed effect will differ from that of one bank firms which bank with just "Bank A" or just "Bank B" and from multibank firms which bank with, for example, "Bank A" and "Bank C".
} 
large companies are required to report full balance sheet and profit and loss accounts (Evans and Ritchie, 2009). Furthermore, FAME is a live database; information on key variables such as company structure and director information is thus only accurate at the time the database is accessed. To mitigate this issue, we have used discs of the FAME database over time and have archived the database at six-monthly intervals over the January 2005 to August 2015 period to capture information when it is first reported. Using this database, we can start our panel in 2002 .

Banks We retrieve accounting data for banks from the Bank of England's Historical Banking Regulatory Database (HBRD). The HBRD reports financial statements and confidential regulatory information for all authorized UK banks and building societies, both at the consolidated (group) level and the standalone (bank) level.

Real Estate Prices To proxy for collateral values, we use monthly regional repeat-sales house price data for 204 regions in England, Wales and Scotland since 1995 as reported in the Land Registry Price Paid dataset. We match this data to individual companies using the registered office postcode reported in FAME. The variation in the evolution of real estate prices across over our sample horizon (2002-2013) is substantial; it varies between $-43 \%$ (Kingston upon Hull) and 288\% (Aberdeenshire).

\subsection{Variables Measurement}

Corporate Collateral FAME reports the value of a firm's "Land and Buildings". We do not use this item as our preferred measure of collateral values given because firms en- 
dogenously choose the quantity of collateral they hold. ${ }^{7}$ Instead, we follow Benmelech and Bergman (2009), Chaney, Sraer, and Thesmar (2012) and Bahaj, Foulis, and Pinter (2016) and exploit fluctuations in collateral prices only. In essence, we measure the value of a firm's land and buildings at the start of the sample, and iterate it forward as a function of changes in local real estate prices. Specifically, our measure is:

$$
\text { Collateral }_{i, t}=\text { Land Holdings }_{i, 2002} \frac{{\text { Land } \text { Price }_{j, t}}_{\text {Land Price }_{j, 2002}}}{\text { Lurnover }_{i, t-1}},
$$

where Land Holdings $s_{i, 2002}$ is the book value of land and buildings owned by the firm at the start of the sample (2002), and Land Prices $_{j, t}$ is the real estate price index for the region where a firm has its registered office. We scale our measure of Collateral using the Turnover of the firm in the previous year. ${ }^{8}$ We select 2002 as our base year to preserve a sufficient number of observations. ${ }^{9}$

Corporate Investment and Controls Our preferred measure of corporate investment is :

$$
\text { Investment }_{i, t}=\frac{\triangle \text { Fixed }_{\text {Asset }}{ }_{i, t}+\text { Depreciation }_{i, t}}{\text { Turnover }_{i, t-1}}
$$

We compute the following controls. First, we compute firms' Cash Ratio (Bank DepositsOverdrafts) and Profit Margin (Operating Profit), both scaled by lagged turnover. To

\footnotetext{
${ }^{7}$ This could either be because the firm has invested in land in anticipation of future growth, or because investment decisions are serially correlated (for example, a firm that buys a new building one year, may be much less likely to buy a new building in the following year).

${ }^{8}$ Alternatively, we could have used fixed assets as the scaling variable, which would be closer to the approach of Chaney, Sraer, and Thesmar (2012) which uses property plant and equipment as the scaling variable. However, unlike their dataset, ours is not limited to listed and relatively large companies, but includes a large number of small companies with potentially small amounts of fixed assets. The choice of turnover as a scaling variable is therefore better suited to our sample, and avoids placing too much weight on smaller companies with small holdings of fixed assets.

${ }^{9}$ This assumption is restrictive in that it requires firms to have existed since 2002; it is similar to the requirement of Chaney, Sraer, and Thesmar (2012) which looks at Compustat firms in existence since 1993.
} 
avoid extreme outliers, the three variables are winsorised at the 1st and 99th percentile. Firm Age is measured as the logarithm of one plus the number of months since the firm was incorporated. We measure a firm's Credit Score in a given year using the "Quiscore" which is reported in the FAME dataset. The Quiscore is produced by CRIF Decision Solutions Limited and is designed to reflect the likelihood that the company will fail in the following 12 months. Each firm is assigned a value between 0 and 100, with a larger value indicating a lower probability of failure. ${ }^{10}$

Banking Relationships UK companies are required to report charges and mortgages (hereafter "charges") to Companies House within 21 days of their creation date. We use this information to identify bank-firm relationships. We use a textual algorithm to match registered charges to UK banks and building societies. The dataset reports the charge creation date and whether the charge is outstanding. For firms which have an outstanding charge with a bank, we use the charge creation date to proxy for the length of a given bank-firm relationship as follows:

$$
\text { Relationship Length } \text { Li,b,t }=\log \left(1+\text { Months }_{i, b, t}\right) \text {, }
$$

where Month $_{i, b, t}$ is the number of months at time $t$ since a charge was first created between firm $i$ and bank $b .^{11}$ For firms with outstanding bank charges with more than one bank at

\footnotetext{
${ }^{10}$ The scores can be categorised into 5 bands: 0-20 "high risk", 21-40 "caution", 41-60 "normal", 61-80 "stable" and 81-100 "secure". The Quiscore is produced using a proprietary model which considers a range of factors including the financial performance of the firm, the economic conditions the firm faces and the firm's compliance with audit procedures (see, for example, Bo, Lensink, and Murinde (2008) for more details).

${ }^{11}$ It is important to note that the archiving of FAME discs at a six-monthly frequency does not affect the accuracy of our relationship length measure. Since firms must report the date on which charges are created, we can accurately calculate the length of the relationship as the difference between the charge creation date and the statement date of their accounts.
} 
a given point in time, we average Relationship Length for all of the outstanding banking relationships a firm has. We exclude firms which do not have any outstanding bank charges from our analysis. The literature has used proxies for relationship intensity other than duration, such as the number of past interactions or their size (Bharath, Dahiya, Saunders, and Srinivasan, 2009). The limitations of our data do not allow us to consider these alternatives.

Bank Controls In some specifications, we control for the following bank characteristics, as measured at the banking group level: size (log total assets), net charge-offs and leverage (Tier 1 capital to total assets).

\subsection{Sample and Summary Statistics}

Our sample includes all private and public UK companies which report to Companies House between 2002 and 2013. Following Chaney, Sraer, and Thesmar (2012) and Kleiner (2015), we exclude firms in the agriculture, utilities, construction, finance and insurance, real estate and public administration sectors. ${ }^{12}$ To avoid double counting, we exclude companies that have a parent with an ownership stake exceeding 50\%. We further drop firms without any outstanding banking relationships, or which do not report fixed assets, depreciation, collateral, operating profit and cash rate. Since reporting requirements differ across companies, this screening reduces the size of our sample. Table 1 reports the proportion of firms in FAME for our selected industries which report banking relationships and the balance sheet and profit and loss items above. Around $15 \%$ of firms report a banking relationship. While Total Assets and Fixed Assets are relatively well reported (96\% and 85\% of observations

\footnotetext{
${ }^{12}$ The UK 2003 Standard Industrial Classification [SIC] codes we exclude are: mining (1010-1450), utilities (4011-4100), construction (4511-4550), finance and insurance (6511-6720), real estate (7011-7032), and public administration (7511-7530).
} 
respectively), Land and Buildings and Turnover are reported less frequently (59\% and $18 \%$ of observations). The final sample has 115,284 firm-year observations covering 27,572 firms.

As shown in Table 1, the firms in our selected sample tend to be larger, employ more workers and have greater turnover than the average firm in the full FAME dataset. Still, the representative firm in the sample is fairly small, with a median turnover around $£ 1.6$ million. The average turnover is substantially higher, reflecting a small number of very large firms. The median value for collateral as a percentage of firm turnover is around $2 \%$.

Table 2 reports summary statistics for our sample, categorised by the number of banking relationships firms have. Almost $90 \%$ of the observations have outstanding charges with just one bank (henceforth "single-bank firms"). Just over 10\% of the observations have outstanding charges with more than one bank ("multiple-bank firms"), a large majority of which have two relationships. The median banking relationship for single-bank firms is around 8.8 years in length, against 8.2 years for multiple-bank firms. The UK banking system is highly concentrated; as a result, four banking groups account for around $90 \%$ of single-bank firm observations.

Our sample is representative of the UK economy despite these screenings. Table 4 shows the distribution of employment in our sample across our selected industries, using the UK 2003 Standard Industrial Classification (SIC). We compare the distribution of employment with the distribution in the overall FAME dataset (which does not condition on firms reporting the variables described above) and also the aggregate employment distribution using "Workforce jobs" data from the Office for National Statistics. The distribution of employment across industries in our selected sample is similar to that of the overall FAME dataset. Relative to the aggregate data, the share of employment in education and health and so- 
cial care is very small in our sample, since we focus on employment within UK companies. The share of employment in manufacturing is notably higher in our sample relative to the aggregate data.

\section{Collateral Channel and Corporate Relationships}

\subsection{Baseline Results}

Corporate Collateral Channel We begin by assessing the strength of the direct collateral channel, measured by the coefficient $\beta$ in equation 2.1. Column 1 of Table 5 reports the results of a regression of corporate investment against collateral and our preffered set of fixed effects only. The results suggest that a $£ 1$ increase in the value of corporate collateral increases investment by around $£ 0.04$. This finding is of a comparable magnitude to the evidence presented by Chaney, Sraer, and Thesmar (2012), which suggests that US public firms increase investment by around $\$ 0.06$ in response to a $\$ 1$ increase in the value of corporate collateral.

In column 2, we add our preferred set of controls. In addition to the firm characteristics listed in the table, the set of controls includes the interactions of quintiles of Firm Age, Profit Margin and Total Assets (as measured in 2002) with the index of local real estate prices. We do so following Chaney, Sraer, and Thesmar (2012) because this index is used to measure Collateral, which creates a potential omitted variable problem for the identification of our regressor of interest Collateral $\times$ Relationship Length. These additional controls leave the estimate of the direct collateral channel unchanged. 
Collateral Channel and Banking Relationships In column 3 of Table 5, we test our preferred specification by including the interaction of Collateral with Relationship Length. For ease of comparison with columns 1 and 2, we measure Relationship Length in deviation from its sample average. Therefore the coefficient on firm collateral ( $\beta$ in Equation 2.1) captures the magnitude of the collateral channel for a firm with Relationship Length equal to the sample mean.

The estimated coefficient on Collateral $\times$ Relationship Length , reported in column 3, suggests that longer banking relationships are associated with a significantly weaker collateral channel. The strength of the collateral channel is weaker for firms which have longer banking relationships. Specifically, the estimated coefficient suggests that a doubling in relationship length reduces the strength of the collateral channel by around $£ 0.02 .{ }^{13}$ To provide some context to these results, a firm with an average relationship length equal to the 75 th percentile (15.4 years) increases investment by around $50 \%$ less than a firm in the 25th percentile $(4.2$ years) in response to a collateral shock of the same value.

Firm investment could be affected by house prices and the interaction of house prices and relationship length regardless of whether firms own commercial property, for instance through a demand channel. In column 4 of Table 5, we include the index of house prices and its interaction with Relationship Length as controls. Both the coefficient for the collateral channel and its interaction with relationship length remain significant.

Private vs. Public Firms If banking relationships serve to overcome informational asymmetries between banks and firms, the impact of banking relationship length on the collateral channel should be reduced for firms which face less informational constraints. Publicly listed

\footnotetext{
${ }^{13}$ Recall that Relationship Length is measured in natural logarithms, as described in Equation 3.2.
} 
firms are typically thought to be less affected by information frictions in banking relationships. One reason is that these firms are required to disclose more information, which may reduce the informational asymmetries associated with lending contracts. In addition, public firms can more readily access market-based funding, and can thus circumvent frictions in access to bank finance.

In columns 5-6 of Table 5, we report the results of running our baseline regression separately for private and public firms. Consistent with our prior, the results suggest that the interaction between relationship and collateral is only statistically significant for private firms.

Corporate Borrowing To explore the mechanism through which firm collateral and banking relationships impact on corporate investment, we re-estimate our baseline model using short-term debt issuance and long-term debt issuance as the dependent variable. The results in columns 7 and 8 of Table 5 suggest that higher collateral values are associated with increases in both short-term and long-term debt issuance. A $£ 1$ increase in corporate collateral increases short-term corporate debt issuance by around $£ 0.011$ and long-term debt issuance by around $£ 0.012$. By contrast, the interaction of collateral and relationship length is associated with an increase in long-term debt (Column 7), but not in short-term debt (Column 6).

Overall, the results suggest that longer banking relationships reduce the strength of the collateral channel, and that this effect coincides with firms with longer relationships reducing their long-term borrowing by less when collateral values decline. These findings support the notion that collateral and private information act as substitutes in mitigating asymmetric 
information in long-term debt contracts.

\subsection{Robustness}

\subsubsection{Additional Interactions}

We now explore whether our key result is driven by time-varying firm or bank characteristics which could be correlated with collateral holdings and relationship length, and might affect corporate investment. To do so, we successively add a number of relevant controls to our baseline regression, as well as their interaction with Collateral and Relationship Length. Table 6 reports the results; column 1 reproduces our baseline specification for ease of comparison.

First, collateral holdings and relationship length could be systematically linked to their age and size. The results in columns 2 to 3 indicate that adding relevant proxies do not affect our key conclusion. Second, riskier firms might also differ in their collateral usage and the nature of their lending relationships. The results in column 4 suggest that controlling for firms' credit rating does not affect the main result either.

A second concern is that firms' preferred relationship length might be related to the characteristics of banks (Schwert, 2018). Different banks might also differ in their collateral requirements. In columns 5 to 7 , we thus add controls for the lender size, leverage, and nonperforming loans. ${ }^{14}$ None of these additional controls change our main result. Finally, as the summary statistics presented in Table 2 show, firms with a single bank relationship tend to differ from multiple-bank firms in several dimensions. In particular, single-bank firms are

\footnotetext{
${ }^{14}$ Following the approach taken to measure Relationship Length for multiple-bank firms, we average Bank Size, Bank Leverage and Bank Losses across all the banks a firm has relationships with in a given year. We also demean all of the variables which we interact with Collateral.
} 
smaller, invest less and have less collateral on average. The results in column 8 show that adding a dummy for multiple-bank firms does not affect our results either.

\subsubsection{Instrumental Variable Approach}

Our measure of real estate prices could be correlated with the unobserved error term, $\varepsilon_{i, t}$. This may be the case if there is reverse causation, whereby investment by large companies in a given region impacts on real estate prices in that region. A second reason why this may be the case is that our measure of real estate prices may be correlated with omitted variables, for example local demand shocks, which affect firm investment. The use of region-time fixed effects $\left(\delta_{j, t}\right)$ in our baseline specification provides a first line of defense against biases related to regional demand shocks associated with house price fluctuations. A complementary strategy is to instrument real estate prices with a variable correlated with collateral values but uncorrelated with the unobserved error term $\varepsilon_{i, t}$. Starting with Saiz (2010), the existing literature has mostly used measures of housing supply elasticity as instruments for real estate prices.

Arguably the problem of reverse causality is likely to be less severe for our sample, which is dominated by relatively small firms, compared to studies focused on larger firms such as Chaney, Sraer, and Thesmar (2012). To mitigate remaining concerns, we adapt the approach of Saiz (2010) to our sample; specifically, we instrument for real estate prices in region $j$ by interacting a measure of mortgage demand - the interest rate on 2-year 75\% LTV mortgages as collected by the Bank of England - with a measure of geographic constraints on the supply of housing in region $j$. We use a measure of local housing supply constraints constructed by Hilber and Vermeulen (2016), which considers the share of developable land that was 
developed in 1990. For regions with a more inelastic supply of housing, a given shift in demand should have a larger impact on real estate prices.

The first-stage regression for our instrumental variables approach is :

$$
\text { Land Price }_{j, t}=b_{0, j}+b_{1 t}+b_{2} \times \text { elasticity }_{j} \times i_{t}+\epsilon_{j, t},
$$

where:

$b_{0, j} \quad$ is a region fixed effect

$b_{1, t} \quad$ is a time fixed effect, capturing macroeconomic fluctuations in real estate prices

elasticity $_{j}$ measures the constraints on land supply in region $\mathrm{j}$

$i_{t} \quad$ is the nationwide mortgage rate at a monthly frequency

$\epsilon_{j, t} \quad$ is an unobserved error term

We then use the predicted regional real estate price indices from Equation 4.1 to produce our collateral measure, as described by Equation 3.1. Finally, we use this measure and its interaction with Relationship Length to instrument for Collateral and Collateral $\times$ Relationship Length, respectively.

The results are shown in column 2 of Table 7 . For comparability, column 1 shows the baseline OLS results. For the instrumental variables approach, the direct corporate collateral channel is significant and larger in magnitude to our baseline results. The estimated coefficient on the interaction of Collateral with Relationship Length is also significant and is slightly more negative than in the baseline results. 


\subsubsection{Robustness Checks}

We now perturb our baseline model in different ways; results are reported in Table 7. First, our results could be biased by the requirement that firms are present in the sample in 2002, when we fix the value of Land Holdings. For robustness, we fix the market value of Land Holdings at time $t-5$ and compute the value of collateral by iterating forward using changes in the regional real estate prices between time $t-5$ and $t$. The value of collateral for firm $i$ in region $j$ at time $t$ is therefore given by:

$$
\text { Collateral }_{i, t}=\text { Land Holding }_{i, t-5} \times \frac{\text { Land Price }_{j, t}}{\text { Land Price } j, t-5} \times \frac{1}{\text { Turnover }_{i, t-1}}
$$

The results, presented in column 3 of Table 7 show that the key results remain qualitatively unchanged.

Real Estate Price Index Our measure of collateral uses residential house prices to proxy for commercial real estate prices. We do so because of the wide regional coverage of house price data. One drawback is that commercial real estate prices might not correlate perfectly with residential house prices. We therefore re-estimate Collateral using commercial real estate prices from the Investment Property Databank. Commercial real estate price indices are only available for major UK cities, whereas residential house prices are available at the local authority level. As a result, our sample size using this approach is much lower. The results in column 4 of Table 7 , show that both the direct collateral channel and the interaction of collateral with banking relationship length remain significant and of comparable magnitude.

Relationship Length Measure The decision by banks and firms to maintain relationships may be endogenous to the firm's investment environment. For example, banks may 
break relationships with firms which have poor investment opportunities; in turn, investment opportunities might be correlated with the firm's collateral values. To mitigate this concern, we lag Relationship Length by two years. The results in column 5 of Table 7 are qualitatively unchanged from the baseline specification.

Investment Measures Next, we explore alternative dependent variables. Column 6 uses investment excluding depreciation and column 7 uses investment in tangibles. The results indicate that the corporate collateral channel and the interaction of collateral and relationship length are significant using both of these alternative measures of investment.

Geographical and Product Mix Our baseline measure of firm collateral uses the house price index for the region where a firm has its registered office. However, some firms operate across multiple regions. We are able to identify these firms using the "Trading Addresses" variable in the Bureau van Dijk dataset. The results, reported in Column 8 of Table 7 , show that the key results are unchanged when excluding multiple-region firms from the sample.

Our baseline sample excludes companies that have a parent with an ownership stake exceeding 50\%. This is to avoid counting subsidiaries twice. Albeit sensible for those groups which only operate in the UK, this approach might fail to address problems related to multinational groups. The balance sheet of these groups will reflect both their domestic and overseas operations and so changes in the value of collateral may not affect investment behaviour in the same way. Furthermore, looking at UK banking relationships may be less relevant for these multinationals if they have many overseas banking relationships. We identify UK-only firms as those firms which have total Turnover equal to "UK turnover" in the Bureau van Dijk dataset. Since some firms do not report this variable, we are unable to 
identify all UK focused firms using this approach. The results reported in column 9 of Table 7 suggest that our key results are not changed when considering only those firms which we identify as UK-focused.

Our baseline specification includes region-time fixed effects to control for local demand effects. This approach would not suffice if firms' response to local demand conditions is determined by factors correlated simultaneously with their collateral holdings and relationship length. As a robustness check, in column 10 of Table 7 we consider whether our results differ when considering only firms which operate in the manufacturing sector. Since these firms are likely to produce tradable goods, they are likely to be relatively insensitive to local demand conditions (Adelino, Schoar, and Severino, 2015). The key results remain unchanged.

\section{Collateral Channel and Personal Relationships}

In line with previous literature (Petersen and Rajan, 1994), our focus thus far has been on the length of the relationship between a firm and its bank. However, personal relationships between financial intermediaries and corporate executives might also help to mitigate corporate borrowing constraints. This can be for three main reasons. Private information about company executives can improve the lender's ability to assess a firm's creditworthiness (Karolyi, 2018); company owners offer personal guarantees on their firm's debt by pledging their own houses - particularly for SME loans (Avery, Bostic, and Samolyk, 1998; Voordeckers and Steijvers, 2006; Ono and Uesugi, 2009); finally, owners can re-mortgage their own house and inject equity into their firms.

These clues are relevant to our study for two reasons. First, personal relationships could 
act as a substitute for corporate relationships, and personal (outside) collateral could constitute a substitute for corporate (inside) collateral. ${ }^{15}$ Controlling for both corporate and personal relationships thus matters for identification to the extent that they might be correlated empirically. Second, personal guarantees are particularly prevalent among UK firms, with around $40 \%$ of SME loans secured by residential real estate (Bahaj, Foulis, and Pinter, 2016). As a result, UK firms' investments are strongly responsive to fluctuations in the value of their directors' house prices.

Our dataset has two key features in this context. First, FAME reports the identity of a given firm's director(s) - that is, the individual(s) who have a statutory obligation to run and contribute to the success of the company. Second, we can use the directors' residential address reported in FAME to identify the potential holder of the mortgage on the director's house, as reported in the Financial Conduct Authority's Product Sales Database. ${ }^{16}$

We thus now consider whether bank-firm relationships insulate corporate investment from collateral value shocks to a larger extent for firms whose directors do not have a personal mortgage relationship with the firm's bank. We create a dummy Director R'ship - 1 for firms with common bank-firm and bank-director relationships, and 0 otherwise. Our main interest is in the interaction between this dummy and our key regressor Collateral $\times$ Relationship Length. This coefficient would be positive if director-bank relationships give banks information on the company's executives and/or a personal guarantee on the own house of the director that act as a substitute for the bank-firm relationship. Conversely, the coefficient

\footnotetext{
${ }^{15}$ In theory, personal collateral could even be more credible than inside collateral since the owner's personal wealth is at stake (Voordeckers and Steijvers (2006) and references therein).

${ }^{16}$ See Bahaj, Foulis, and Pinter (2016) for a detailed explanation of the matching process. The FCA Product Sales Data include regulated mortgage contracts only, and therefore exclude other regulated home finance products such as home purchase plans and home reversions, and unregulated products such as second charge lending and buy-to-let mortgages.
} 
would be negative if the director-bank relationship allows the bank to make a better use of the bank-firm relationship.

The results, reported in column 2 of Table 8, are consistent with the first conjecture. The estimates show that the interaction between Collateral and DirectorRelationship is not statistically significant. In other words, the direct collateral channel is not materially different for firms with or without a common firm-director banking relationships.

In contrast, the interaction of Collateral $\times$ Relationship Length and DirectorRelationship is positive and statistically significant. This suggests that our key mechanism whereby corporate lending relationships insulate investment from fluctuations in collateral values is substantially weaker for firms whose directors also maintain personal relationships with their firm's banks. In other words, corporate relationships only act as a substitute for collateral for firms in which there is no common firm-director banking relationship. The bottom line is that personal relationships seem to be a substitute for corporate relationships.

Our data do not allow us to ascertain whether these results reflect corporate directors pledging their own house as collateral or the firm's bank gaining private information about directors through its mortgage relationship. However, our data provide information on whether a given director is also a shareholder in the firm. Non-shareholder directors - most likely high-level company executives - cannot pledge their own house as guarantee for the firm borrowing.

In column 5 of Table 8 we thus introduce an additional dummy variable Shareholder one if the common director-bank relationship is that of a shareholder of the firm, and 0 otherwise. First, the results show that the interaction between Shareholder and Collateral $\times$ Relationship Length $\times$ Director Relationship is not statistically significant. This suggests 
that the substitutability between personal and corporate relationships in insulating corporate investment from real-estate value shocks is not different across the two types of directors. Second, the coefficient for Collateral $\times$ Relationship Length $\times$ Director Relationship remains positive and statistically significant. This term captures the substitutability between personal and corporate relationships in insulating corporate investment from real-estate value shocks for firms whose common personal relationships are those of non-shareholder directors. Taken at face value, the finding that this effect is significant suggests that the presence of a common relationship may reduce the importance of banking relationship length by reducing informational asymmetries about the management of the firm, rather than by shareholders additionally pledging their own houses to secure their firm's debt.

\section{Conclusion}

This paper shows that the collateral channel diminishes in strength when firms and their executives maintain long-term relationships with a bank. Concretely, UK firms' investment is less responsive to changes in the value of their real estate collateral when their ongoing lending relationships are longer. This finding is consistent with seminal theories arguing that collateral and private information are two complementary ways to mitigate similar contracting frictions (Holmstrom and Tirole, 1997); it contradicts alternative models presenting collateral and private information as complements (Rajan, 1992).

The notion of self-reinforcing swings in asset prices and economic activity has led to calls for macroprudential policies aimed at curbing cycles in real estate prices, such as loan-tovalue limits and counter-cyclical buffers. Our results suggest that the transmission of these 
interventions to corporate investment is likely to depend on the intensity of firms' lending relationships. Understanding how the nature of corporate borrowing might evolve in a context of sweeping technological and structural changes in banking and financial markets could help inform policies aimed at taming future credit cycles. 


\section{References}

Adelino, M., A. Schoar, and F. Severino (2015): "House prices, collateral, and selfemployment," Journal of Financial Economics, 117(2), 288-306.

Avery, R. B., R. W. Bostic, and K. A. SAmolyk (1998): "The role of personal wealth in small business finance," Journal of Banking \& Finance, 22(6-8), 1019-1061.

Bahaj, S., A. Foulis, And G. Pinter (2017): "Home Values and Firm Behaviour," Discussion Papers 1724, Centre for Macroeconomics (CFM).

Banerjee, R., And K. Blickle (2016): "Housing collateral and small firm activity in Europe," Unpublished.

Banerjee, R., L. Gambacorta, and E. Sette (2017): "The real effects of relationship lending," Unpublished.

Beck, T., H. Degryse, R. De HaAs, and N. Van Horen (2018): "When arm's length is too far: Relationship banking over the credit cycle," Journal of Financial Economics, 127(1), 174-196.

Benmelech, E., and N. K. Bergman (2009): "Collateral pricing," Journal of financial Economics, 91(3), 339-360.

Berger, A., And G. Udell (1995): "Relationship Lending and Lines of Credit in Small Firm Finance," The Journal of Business, 68(3), 351-81.

Berger, A. N., W. Frame, and V. IoAnnidou (2011): "Tests of ex ante versus ex post theories of collateral using private and public information," Journal of Financial Economics, 100(1), 85-97.

Bernanke, B., And M. Gertler (1989): "Agency Costs, Net Worth, and Business Fluctuations," American Economic Review, 79(1), 14-31.

Besanko, D., and A. Thakor (1987): "Collateral and Rationing: Sorting Equilibria in Monopolistic and Competitive Credit Markets," International Economic Review, 28(3), $671-89$.

Bester, H. (1985): "Screening vs. Rationing in Credit Markets with Imperfect Information," American Economic Review, 75(4), 850-55.

Bharath, S. T., S. Dahiya, A. Saunders, and A. Srinivasan (2009): "Lending relationships and loan contract terms," The Review of Financial Studies, 24(4), 11411203.

Bo, H., R. Lensink, And V. Murinde (2008): "Credit Ratings and Corporate Investment: UK Evidence," SOAS Centre for Financial and Management Studies, Discussion Paper, Discussion Paper 95. 
Bolton, P., And X. Freixas (2000): "Equity, Bonds, and Bank Debt: Capital Structure and Financial Market Equilibrium under Asymmetric Information," Journal of Political Economy, 108(2), 324-351.

Bolton, P., X. Freixas, and L. Gambacorta (2016): "Relationship and Transaction Lending in a Crisis*," Review of Financial Studies.

Boot, A. (2000): "Relationship Banking: What Do We Know?," Journal of Financial Intermediation, 9(1), 7-25.

Boot, A. W. A., A. V. Thakor, and G. F. Udell (1991): "Secured Lending and Default Risk: Equilibrium Analysis, Policy Implications and Empirical Results," Economic Journal, 101(406), 458-72.

Brick, I. E., And D. Palia (2007): "Evidence of jointness in the terms of relationship lending," Journal of Financial Intermediation, 16(3), 452-476.

Cerqueiro, G., S. Ongena, and K. Roszbach (2016): "Collateral damage? On collateral, corporate financing and performance," Working Paper Series 1918, European Central Bank.

Chaney, T., D. Sraer, and D. Thesmar (2012): "The Collateral Channel: How Real Estate Shocks Affect Corporate Investment," American Economic Review, 102(6), 23812409.

Cvijanovic, D. (2014): "Real Estate Prices and Firm Capital Structure," Review of Financial Studies, 27(9), 2690-2735.

DeYoung, R., A. Gron, G. Torna, and A. Winton (2015): "Risk overhang and loan portfolio decisions: small business loan supply before and during the financial crisis," The Journal of Finance, 70(6), 2451-2488.

Dougal, C., C. A. Parsons, and S. Titman (2015): "Urban Vibrancy and Corporate Growth," The Journal of Finance, 70(1), 163-210.

Ersahin, N., and R. M. Irani (2015): "Collateral Values and Corporate Employment," Working Papers 15-30, Center for Economic Studies, U.S. Census Bureau.

Evans, P., And F. Ritchie (2009): "UK company statistics reconciliation project," Department for Business, Enterprise and Regulatory Reform.

Flannery, M., And L. Lin (2016): "House prices, bank balance sheets, and bank credit supply," Working Paper.

Fort, T. C., J. Haltiwanger, R. S. Jarmin, and J. Miranda (2013): "How firms respond to business cycles: The role of firm age and firm size," IMF Economic Review, $61(3), 520-559$.

Froot, K., D. Scharfstein, and J. Stein (1993): "Risk Management: Coordinating Corporate Investment and Financing Policies," Journal of Finance, 48(5), 1629-58. 
GAN, J. (2007): "Collateral, debt capacity, and corporate investment: Evidence from a natural experiment," Journal of Financial Economics, 85(3), 709-734.

Gertler, M. (1992): "Financial capacity and output fluctuations in an economy with multi-period financial relationships," The Review of Economic Studies, 59(3), 455-472.

Gertler, M., and S. Gilchrist (1994): "Monetary Policy, Business Cycles, and the Behavior of Small Manufacturing Firms," The Quarterly Journal of Economics, 109(2), 309-40.

Giroud, X., And H. M. Mueller (2016): "Firm Leverage and Unemployment during the Great Recession," Quarterly Journal of Economics, (Forthcoming).

Hilber, C. A. L., And W. Vermeulen (2016): "The Impact of Supply Constraints on House Prices in England," Economic Journal, 126(591), 358-405.

Holmstrom, B., and J. Tirole (1997): "Financial Intermediation, Loanable Funds, and The Real Sector," The Quarterly Journal of Economics, 112(3), 663-691.

Jiangli, W., H. Unal, And C. Yom (2008): "Relationship Lending, Accounting Disclosure, and Credit Availability during the Asian Financial Crisis," Journal of Money, Credit and Banking, 40(1), 25-55.

Jimenez, G., S. Ongena, J.-L. Peydro, and J. Saurina (2012): "Credit Supply and Monetary Policy: Identifying the Bank Balance-Sheet Channel with Loan Applications," American Economic Review, 102(5), 2301-26.

Jimenez, G., V. Salas, and J. Saurina (2006): "Determinants of collateral," Journal of Financial Economics, 81(2), 255-281.

Karolyi, S. A. (2018): "Personal lending relationships," The Journal of Finance, 73(1), $5-49$.

Kiyotaki, N., And J. Moore (1997): "Credit Cycles," Journal of Political Economy, 105(2), 211-48.

Kleiner, K. (2015): "Collateral and Small Firm Labor," Kelley School of Business Research.

Manove, M., A. J. Padilla, and M. Pagano (2001): "Collateral versus Project Screening: A Model of Lazy Banks," RAND Journal of Economics, 32(4), 726-44.

Ono, A., And I. Uesugi (2009): "Role of Collateral and Personal Guarantees in Relationship Lending: Evidence from Japan's SME Loan Market," Journal of Money, Credit and Banking, 41(5), 935-960.

Petersen, M. A., And R. G. Rajan (1994): " The Benefits of Lending Relationships: Evidence from Small Business Data," Journal of Finance, 49(1), 3-37.

RAJAn, R. (1992): "Insiders and Outsiders: The Choice between Informed and Arm'sLength Debt," Journal of Finance, 47(4), 1367-400. 
RAJAn, R., AND A. Winton (1995): "Covenants and Collateral as Incentives to Monitor," Journal of Finance, 50(4), 1113-46.

SAIZ, A. (2010): "The Geographic Determinants of Housing Supply," The Quarterly Journal of Economics, 125(3), 1253-1296.

Schwert, M. (2018): "Bank capital and lending relationships," The Journal of Finance.

Sette, E., and G. GobBi (2015): "Relationship lending during a financial crisis," Journal of the European Economic Association, 13(3), 453-481.

Sharpe, S. (1990): "Asymmetric Information, Bank Lending, and Implicit Contracts: A Stylized Model of Customer Relationships," Journal of Finance, 45(4), 1069-87.

Siemer, M. (2014): "Firm Entry and Employment Dynamics in the Great Recession," Finance and Economics Discussion Series 2014-56, Board of Governors of the Federal Reserve System (U.S.).

Voordeckers, W., and T. Steijvers (2006): "Business collateral and personal commitments in SME lending," Journal of Banking $\& 3$ Finance, 30(11), 3067-3086.

Xu, B., H. Wang, and A. V. Rixtel (2015): "Do banks extract informational rents through collateral?," BIS Working Papers 522, Bank for International Settlements. 


\section{A Tables}

Table 1: Summary Statistics- Fame Dataset and Selected Sample

\begin{tabular}{|c|c|c|c|c|}
\hline & \multicolumn{2}{|c|}{ FAME Dataset } & \multicolumn{2}{|c|}{ Selected Sample } \\
\hline & $\%$ which & Median & Coverage in & Median \\
\hline & Report & Value & Sample & Value \\
\hline Total Assets (£000s) & $96 \%$ & 51 & $6 \%$ & 1004 \\
\hline Fixed Assets (£000s) & $85 \%$ & 8 & $7 \%$ & 284 \\
\hline Tangible Assets (£000s) & $84 \%$ & 6 & $9 \%$ & 224 \\
\hline Land and Buildings (£000s) & $59 \%$ & 0 & $12 \%$ & 55 \\
\hline Turnover (£000s) & $18 \%$ & 100 & $11 \%$ & 1574 \\
\hline Number of Employees & $5 \%$ & 22 & $11 \%$ & 73 \\
\hline Banking Relationship & $19 \%$ & & $5 \%$ & \\
\hline Total Firm Year Observations & 11194476 & & & 115284 \\
\hline \multicolumn{5}{|c|}{$\begin{array}{l}\text { Notes: The statistics are calculated for the "FAME Dataset" using all observations for active firms in } \\
\text { our selected industries which report at an annual frequency and our "Selected Sample" using observations } \\
\text { used for our baseline regression, covering the period 2002-2013. Our "Selected Sample" excludes firms that } \\
\text { have an ownership stake greater than } 50 \% \text {, that operate in certain industries, and that do not report the } \\
\text { main variables of interest for our baseline regression. Full details on our "Selected Sample" for the baseline } \\
\text { regression are given in Section } 3.3 \text {. Column } 1 \text { gives the percentage of observations in the "FAME Dataset" } \\
\text { which report the given variables. Column } 2 \text { gives the median value of the given variables in the "FAME } \\
\text { Dataset". Column } 3 \text { shows the coverage of the variables of interest, by value, of our "Selected Sample" and } \\
\text { Column } 4 \text { gives the median value of the given variables in our "Selected Sample". }\end{array}$} \\
\hline
\end{tabular}


Table 2: Summary Statistics for Selected Sample, Categorised by Number of BANKING RELATIONSHIPS

\begin{tabular}{lccc}
\hline & One & Multiple & All \\
\hline Firm-year observations & 101649 & 13635 & 115284 \\
Turnover (£000s, median) & 1400 & 3571 & 1574 \\
Investment (median) & .0086 & .012 & .009 \\
Profit rate (median) & .032 & .028 & .032 \\
Collateral (median) & .011 & .084 & .018 \\
Short term debt (£000s, median) & 89 & 232 & 100 \\
Long term debt (£000s, median) & 151 & 376 & 175 \\
Age (months, median) & 196 & 249 & 204 \\
Relationship length (months, median) & 106 & 98 & 104 \\
\hline
\end{tabular}

Notes: This Table reports corporate activity and banking relationship data for firms in our "Selected Sample", sourced from the FAME Dataset. The sample period is 2002-2013 and covers firms with a banking relationship. Columns 1 and 2 report summary statistics for firms which have outstanding charges with one bank and outstanding charges with multiple banks respectively. Column 3 reports summary statistics for the full sample. Investment is the change in "Fixed Assets" plus "Depreciation, scaled by lagged turnover. Profit rate is defined as "Operating Profit", scaled by lagged turnover. Collateral is defined by Equation 3.1. Short Term Debt is defined as the sum of the change in "Short Term Loans and Overdrafts", scaled by lagged turnover.

Table 3: Banking Groups of One Bank Firms

\begin{tabular}{lcc}
\hline Number of relationships & Observations & Percentage \\
\hline Banking Group 1 & 33451 & 32.9 \\
Banking Group 2 & 23148 & 22.8 \\
Banking Group 3 & 20394 & 20.1 \\
Banking Group 4 & 14259 & 14.0 \\
Banking Group 5 & 4446 & 4.4 \\
Other & 5951 & 5.9 \\
\hline Total & 101649 & 100.0 \\
\hline
\end{tabular}

The Table shows the banking groups which firms have relationships with for firms which have outstanding charges with just one bank. The banking groups are anonymised and are ordered in descending order such that Banking Group 1 is the Banking Group with the most firm-bank relationships. "Other" represents firms which have banking relationships with banking groups other than the five largest banking groups. 
Table 4: Employment Shares for Included Industries, UK 2003 Standard Industrial Classification

\begin{tabular}{|c|c|c|c|c|c|c|c|c|c|c|}
\hline & $\begin{array}{l}\text { Agriculture, } \\
\text { Hunting, } \\
\text { Forestry, } \\
\text { Fishing }\end{array}$ & $\begin{array}{l}\text { Manufac- } \\
\text { turing }\end{array}$ & $\begin{array}{l}\text { Wholesale } \\
\text { and Retail }\end{array}$ & $\begin{array}{l}\text { Hotels } \\
\text { and } \\
\text { Restau- } \\
\text { rants }\end{array}$ & $\begin{array}{c}\text { Transport, } \\
\text { Storage, } \\
\text { Commu- } \\
\text { nications, } \\
\text { Business } \\
\text { Activities }\end{array}$ & Education & $\begin{array}{c}\text { Health } \\
\text { and Social } \\
\text { Work }\end{array}$ & $\begin{array}{c}\text { Other } \\
\text { Commu- } \\
\text { nity, } \\
\text { Social, } \\
\text { Personal } \\
\text { Activities }\end{array}$ & $\begin{array}{c}\text { Activities } \\
\text { of Private } \\
\text { House- } \\
\text { holds }\end{array}$ & $\begin{array}{l}\text { Total Em- } \\
\text { ployment }\end{array}$ \\
\hline \multicolumn{11}{|l|}{2003} \\
\hline Sample & $3 \%$ & $33 \%$ & $22 \%$ & $7 \%$ & $31 \%$ & $0 \%$ & $2 \%$ & $3 \%$ & $0 \%$ & 1373160 \\
\hline FAME & $2 \%$ & $36 \%$ & $23 \%$ & $10 \%$ & $26 \%$ & $0 \%$ & $1 \%$ & $3 \%$ & $0 \%$ & 8000945 \\
\hline ONS & $1 \%$ & $14 \%$ & $20 \%$ & $8 \%$ & $27 \%$ & $10 \%$ & $13 \%$ & $7 \%$ & $1 \%$ & 25098000 \\
\hline \multicolumn{11}{|l|}{2008} \\
\hline Sample & $1 \%$ & $26 \%$ & $24 \%$ & $6 \%$ & $37 \%$ & $0 \%$ & $3 \%$ & $3 \%$ & $0 \%$ & 1343630 \\
\hline FAME & $1 \%$ & $28 \%$ & $24 \%$ & $8 \%$ & $33 \%$ & $0 \%$ & $2 \%$ & $3 \%$ & $0 \%$ & 8880385 \\
\hline ONS & $1 \%$ & $11 \%$ & $19 \%$ & $8 \%$ & $29 \%$ & $10 \%$ & $14 \%$ & $7 \%$ & $1 \%$ & 26193750 \\
\hline \multicolumn{11}{|l|}{2013} \\
\hline Sample & $1 \%$ & $22 \%$ & $28 \%$ & $8 \%$ & $32 \%$ & $0 \%$ & $4 \%$ & $3 \%$ & $0 \%$ & 899776 \\
\hline FAME & $1 \%$ & $24 \%$ & $22 \%$ & $10 \%$ & $37 \%$ & $0 \%$ & $2 \%$ & $4 \%$ & $0 \%$ & 9584456 \\
\hline ONS & $1 \%$ & $10 \%$ & $18 \%$ & $8 \%$ & $30 \%$ & $11 \%$ & $15 \%$ & $7 \%$ & $0 \%$ & 26751500 \\
\hline
\end{tabular}

The Table shows the distribution in total employment across the industries included in our "Selected Sample", the "FAME Dataset" and for the aggregate economy using "Workforce Jobs" data sourced from the ONS. The final column shows the total number of employees covered by the relevant samples. The industrial groupings are based on UK 2003 Standard Industrial Classification (SIC) codes. We exclude firms operating in utilities (2003-SIC: 4011-4100), construction (2003-SIC: 4511-4550), finance and insurance (2003-SIC: 6511-6720), real estate (2003-SIC: 7011-7032), public administration (2003-SIC: 7511-7530), and mining (2003-SIC: 1010-1450) 
Table 5: Corporate Relationships \& the Collateral Channel

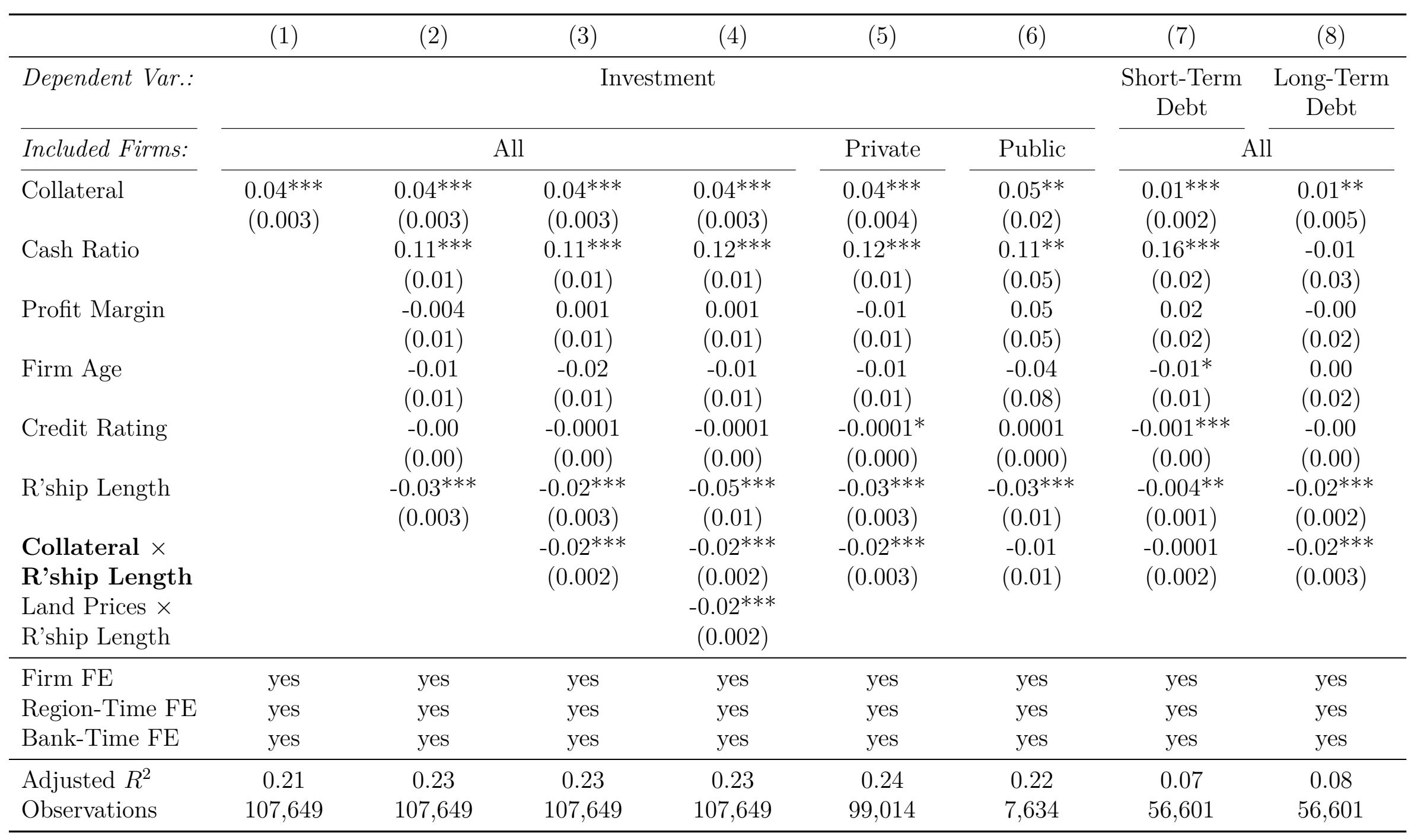

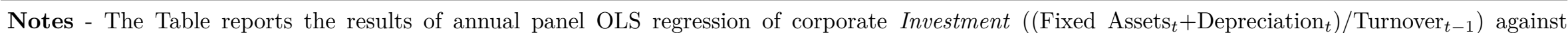

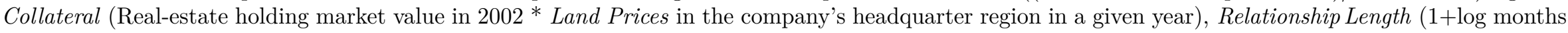

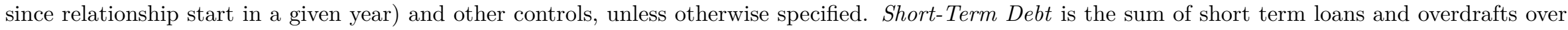

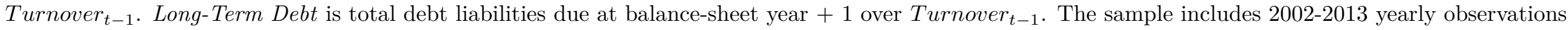

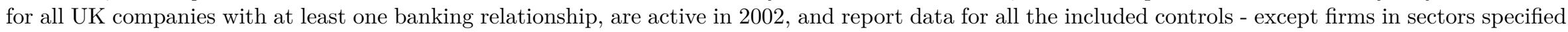

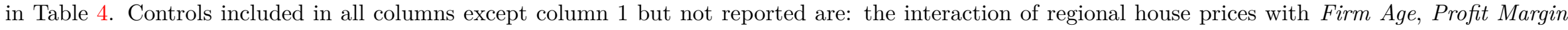

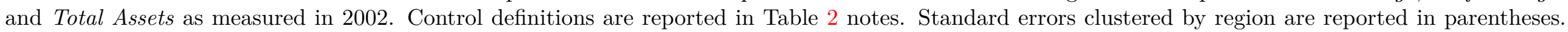
Stars indicate statistical significance at $1 \%(* * *), 5 \%(* *)$, and $10 \%(*)$. 
Table 6: Corporate Relationships \& the Collateral Channel: Additional interactions

\begin{tabular}{|c|c|c|c|c|c|c|c|c|}
\hline & $(1)$ & $(2)$ & $(3)$ & (4) & $(5)$ & $(6)$ & $(7)$ & $(8)$ \\
\hline & Baseline & & & & & & & \\
\hline$X i s:$ & & Firm Age & Small & $\begin{array}{l}\text { Credit } \\
\text { Rating }\end{array}$ & Bank Size & $\begin{array}{c}\text { Bank } \\
\text { Leverage }\end{array}$ & $\begin{array}{l}\text { Bank } \\
\text { Losses }\end{array}$ & $\begin{array}{c}\text { Multiple } \\
\text { Bank }\end{array}$ \\
\hline Collateral & $\begin{array}{c}0.04^{* * *} \\
(0.003)\end{array}$ & $\begin{array}{c}0.04^{* * *} \\
(0.004)\end{array}$ & $\begin{array}{c}0.05^{* * *} \\
(0.004)\end{array}$ & $\begin{array}{c}0.04^{* * *} \\
(0.003)\end{array}$ & $\begin{array}{c}0.04^{* * *} \\
(0.003)\end{array}$ & $\begin{array}{c}0.04^{* * *} \\
(0.003)\end{array}$ & $\begin{array}{c}0.04^{* * *} \\
(0.003)\end{array}$ & $\begin{array}{c}0.04^{* * *} \\
(0.003)\end{array}$ \\
\hline R'ship Length & $\begin{array}{c}-0.02^{* * *} \\
(0.003)\end{array}$ & $\begin{array}{c}-0.03^{* * *} \\
(0.003)\end{array}$ & $\begin{array}{c}-0.02^{* * *} \\
(0.003)\end{array}$ & $\begin{array}{c}-0.03^{* * *} \\
(0.003)\end{array}$ & $\begin{array}{c}-0.03^{* * *} \\
(0.003)\end{array}$ & $\begin{array}{c}-0.02^{* * *} \\
(0.003)\end{array}$ & $\begin{array}{c}-0.02^{* * *} * \\
(0.003)\end{array}$ & $\begin{array}{c}-0.02^{* * *} \\
(0.003)\end{array}$ \\
\hline $\begin{array}{l}\text { Collateral } \times \\
\text { R'ship Length }\end{array}$ & $\begin{array}{c}-0.02^{* * *} \\
(0.002)\end{array}$ & $\begin{array}{c}-0.02^{* * *} \\
(0.002)\end{array}$ & $\begin{array}{c}-0.02^{* * *} \\
(0.002)\end{array}$ & $\begin{array}{c}-0.02^{* * *} \\
(0.002)\end{array}$ & $\begin{array}{c}-0.02^{* * *} \\
(0.002)\end{array}$ & $\begin{array}{c}-0.02^{* * *} \\
(0.002)\end{array}$ & $\begin{array}{c}-0.02^{* * *} \\
(0.002)\end{array}$ & $\begin{array}{c}-0.02^{* * *} \\
(0.002)\end{array}$ \\
\hline Collateral $* \mathrm{X}$ & & $\begin{array}{l}-0.004 \\
(0.004)\end{array}$ & $\begin{array}{c}-0.03^{* * *} \\
(0.004)\end{array}$ & $\begin{array}{c}-0.0001^{*} \\
(0.000)\end{array}$ & $\begin{array}{c}-0.01^{* * *} \\
(0.002)\end{array}$ & $\begin{array}{l}0.0003 \\
(0.002)\end{array}$ & $\begin{array}{c}0.003 \\
(0.003)\end{array}$ & $\begin{array}{l}-0.004 \\
(0.006)\end{array}$ \\
\hline R'ship Length * X & & $\begin{array}{c}0.03^{* * *} \\
(0.003)\end{array}$ & $\begin{array}{c}-0.01^{* * *} \\
(0.001)\end{array}$ & $\begin{array}{c}0.0002^{* * *} \\
(0.000)\end{array}$ & $\begin{array}{c}0.008^{* * *} \\
(0.002)\end{array}$ & $\begin{array}{l}0.0001 \\
(0.001)\end{array}$ & $\begin{array}{l}0.0003 \\
(0.001)\end{array}$ & $\begin{array}{c}0.003 \\
(0.007)\end{array}$ \\
\hline Adjusted $R^{2}$ & 0.23 & 0.23 & 0.24 & 0.23 & 0.23 & 0.23 & 0.23 & 0.23 \\
\hline Observations & 107,649 & 107,649 & 107,646 & 107,649 & 107,649 & 107,649 & 107,649 & 107,649 \\
\hline
\end{tabular}

Notes - The Table reports the results of annual panel OLS regression of corporate Investment ((Fixed Assets $t+$ Depreciation $\left._{t}\right) /$ Turnover $\left._{t-1}\right)$ against Collateral (Real-estate holding market value in $2002 *$ Land Prices in the company's headquarter region in a given year), Relationship Length (1+log months since relationship start in a given year) and other controls. Firm Age is 1 for firms more than 10 years old, 0 otherwise; Small is 1 for firms in the bottom $50 \%$ of the distribution of Total Assets in a given year, 0 otherwise; Credit Score is the firm's Quiscore; Bank Size is the lag log(Total Assets) of the firm's bank; Bank Leverage is the lag ratio of total Tier 1 capital to total assets; Bank Losses is the lag ratio of net loan loss write-offs (gross write-offs less recoveries) to total loans; Multiple Bank is 1 for firms with outstanding charges with more than one bank, 0 otherwise. The sample includes 2002-2013 yearly observations for all UK companies with at least one banking relationship, are active in 2002, and report data for all the included controls - except firms in sectors specified in Table 4. Controls included in all columns but not reported are: Cash Ratio, Profit Margin, Firm Age, Credit Rating, as well the interaction of Land Prices with Firm Age, Profit Margin and Total Assets as measured in 2002. Other controls definitions are reported in Table 2 notes. Standard errors clustered by region are reported in parentheses. Stars indicate statistical significance at $1 \%$ $(* * *), 5 \%(* *)$, and $10 \%(*)$. 
Table 7: Corporate Relationships \& the Collateral Channel: Robustness Checks

\begin{tabular}{|c|c|c|c|c|c|c|c|c|c|c|}
\hline & \multirow{3}{*}{$\begin{array}{c}(1) \\
\text { Baseline }\end{array}$} & \multirow{3}{*}{$\begin{array}{l}(2) \\
\text { IV }\end{array}$} & \multirow{2}{*}{\multicolumn{2}{|c|}{$\begin{array}{c}(3) \\
\text { Collateral measure: }\end{array}$}} & \multirow{3}{*}{$\begin{array}{c}(5) \\
\text { Lag Rela- } \\
\text { tionship }\end{array}$} & \multirow{2}{*}{\multicolumn{2}{|c|}{$\begin{array}{c}(6) \\
\text { Investment measure: }\end{array}$}} & (8) & (9) & $(10)$ \\
\hline & & & & & & & & \multicolumn{3}{|c|}{ Subset of Firms: } \\
\hline & & & At $t-5$ & $\begin{array}{c}\text { Based on } \\
\text { CRE } \\
\text { prices }\end{array}$ & & $\begin{array}{c}\text { ex- } \\
\text { Depreciation }\end{array}$ & $\begin{array}{l}\text { Tangibles } \\
n \text { only }\end{array}$ & $\begin{array}{l}\text { Single- } \\
\text { Region }\end{array}$ & $\begin{array}{c}\text { UK- } \\
\text { Focused }\end{array}$ & $\begin{array}{l}\text { Manufac- } \\
\text { turing }\end{array}$ \\
\hline Collateral & $\begin{array}{c}0.04^{* * *} \\
(0.00)\end{array}$ & $\begin{array}{c}0.06^{* * *} \\
(0.02)\end{array}$ & $\begin{array}{c}0.01^{* * *} \\
(0.00)\end{array}$ & $\begin{array}{l}0.06^{* * *} \\
(0.01)\end{array}$ & $\begin{array}{c}0.03^{* * *} \\
(0.00)\end{array}$ & $\begin{array}{c}0.02^{* * *} \\
(0.00)\end{array}$ & $\begin{array}{c}0.03^{* * *} \\
(0.00)\end{array}$ & $\begin{array}{c}0.04^{* * *} \\
(0.00)\end{array}$ & $\begin{array}{c}0.04^{* * *} \\
(0.01)\end{array}$ & $\begin{array}{c}0.03^{* * *} \\
(0.01)\end{array}$ \\
\hline $\begin{array}{l}\text { Collateral } \times \\
\text { R'ship Length }\end{array}$ & $\begin{array}{c}-0.02^{* * *} \\
(0.00)\end{array}$ & $\begin{array}{c}-0.02^{* * *} \\
(0.01)\end{array}$ & $\begin{array}{c}-0.01^{* * *} \\
(0.00)\end{array}$ & $\begin{array}{c}-0.03^{* * *} \\
(0.00)\end{array}$ & $\begin{array}{c}-0.01^{* * *} \\
(0.00)\end{array}$ & $\begin{array}{c}-0.02^{* * *} \\
(0.00)\end{array}$ & $\begin{array}{c}-0.02^{* * *} \\
(0.00)\end{array}$ & $\begin{array}{c}-0.02^{* * *} \\
(0.00)\end{array}$ & $\begin{array}{c}-0.02^{* * *} \\
(0.00)\end{array}$ & $\begin{array}{c}-0.01^{*} \\
(0.01)\end{array}$ \\
\hline Adjusted $R^{2}$ & 0.23 & 0.23 & 0.22 & 0.25 & 0.22 & 0.15 & 0.24 & 0.24 & 0.25 & 0.20 \\
\hline Observations & 107,649 & 97,989 & 76,239 & 49,909 & 94,347 & 11,7967 & 10,7347 & 78,919 & 33,510 & 22,421 \\
\hline
\end{tabular}

Notes - The Table reports the results of annual panel OLS regression of corporate Investment ((Fixed Assets $t+$ Depreciation $\left._{t}\right) /$ Turnover $\left._{t-1}\right)$ against $_{\text {Collateral }}$ (Real-estate holding market value in $2002 *$ Land Prices in the company's headquarter region in a given year), Relationship Length (1+log months since relationship start in a given year) and other controls, unless otherwise specified. The sample includes 2002-2013 yearly observations for all UK companies with at least one banking relationship, are active in 2002, and report data for all the included controls - except firms in sectors specified in Table 4. Controls included in all columns but not reported are: Cash Ratio, Profit Margin, Firm Age, Credit Rating, as well the interaction of Land Prices with Firm Age, Profit Margin and Total Assets as measured in 2002. Control definitions are reported in Table 2 notes. Standard errors clustered by region are reported in parentheses. Stars indicate statistical significance at $1 \%\left({ }^{* * *}\right), 5 \%(* *)$, and $10 \%(*)$. 
Table 8: Personal Relationships \& the Collateral Channel

\begin{tabular}{|c|c|c|c|c|c|}
\hline & $(1)$ & $(2)$ & $(3)$ & $(4)$ & $(5)$ \\
\hline Included Firms: & \multicolumn{2}{|c|}{ All } & Private & Public & All \\
\hline Collateral & $\begin{array}{l}0.04^{* * *} \\
(0.003)\end{array}$ & $\begin{array}{l}0.04^{* * *} \\
(0.003)\end{array}$ & $\begin{array}{l}0.04^{* * *} \\
(0.003)\end{array}$ & $\begin{array}{l}0.05^{* *} \\
(0.02)\end{array}$ & $\begin{array}{l}0.04^{* * *} \\
(0.003)\end{array}$ \\
\hline Collateral * R'ship Length & $\begin{array}{c}-0.02^{* * *} \\
(0.002)\end{array}$ & $\begin{array}{c}-0.02^{* * *} \\
(0.002)\end{array}$ & $\begin{array}{c}-0.02^{* * *} \\
(0.002)\end{array}$ & $\begin{array}{c}-0.02 \\
(0.011)\end{array}$ & $\begin{array}{c}-0.02^{* * *} \\
(0.003)\end{array}$ \\
\hline Collateral * Director R'ship & & $\begin{array}{l}-0.01 \\
(0.01)\end{array}$ & $\begin{array}{l}-0.01 \\
(0.01)\end{array}$ & $\begin{array}{l}-0.01 \\
(0.01)\end{array}$ & $\begin{array}{c}0.05 \\
(0.06)\end{array}$ \\
\hline R'ship Length * Director R'ship & & $\begin{array}{c}0.001 \\
(0.001)\end{array}$ & $\begin{array}{c}-0.0000 \\
(0.001)\end{array}$ & $\begin{array}{c}0.001 \\
(0.001)\end{array}$ & $\begin{array}{c}-0.003 \\
(0.004)\end{array}$ \\
\hline Collateral * R'ship Length * Director R'ship & & $\begin{array}{l}0.02^{* * *} \\
(0.006)\end{array}$ & $\begin{array}{l}0.02^{* * *} \\
(0.007)\end{array}$ & $\begin{array}{l}-0.04 \\
(0.06)\end{array}$ & $\begin{array}{l}0.02^{* * *} \\
(0.006)\end{array}$ \\
\hline Collateral * Director R'ship * Shareholder & & & & & $\begin{array}{c}0.02 \\
(0.013)\end{array}$ \\
\hline Length * Director R'ship * Shareholder & & & & & $\begin{array}{c}0.002 \\
(0.002)\end{array}$ \\
\hline Collateral * Length * Director R'ship * Shareholder & & & & & $\begin{array}{l}-0.01 \\
(0.01)\end{array}$ \\
\hline Adjusted R-Squared & 0.23 & 0.23 & 0.24 & 0.22 & 0.23 \\
\hline Observations & 107,649 & 107,649 & 99,014 & 7,634 & 107,649 \\
\hline
\end{tabular}

Notes - The Table reports the results of annual panel OLS regression of corporate Investment ((Fixed Assets + Depreciation $\left._{t}\right) /$ Turnover $\left._{t-1}\right)$ against Collateral (Real-estate holding market value in $2002 *$ Land Prices in the company's headquarter region in a given year), Relationship Length (1+log months since relationship start in a given year) and other controls, unless otherwise specified. Short-Term Debt is the sum of short term loans and

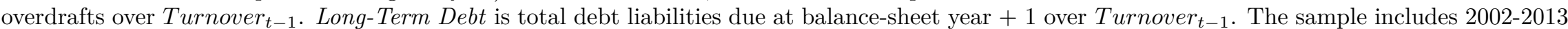
yearly observations for all UK companies with at least one banking relationship, are active in 2002, and report data for all the included controls - except firms in sectors specified in Table 4. Controls included in all columns but not reported are: Cash Ratio, Profit Margin, Firm Age, Credit Rating, as well the interaction of Land Prices with Firm Age, Profit Margin and Total Assets as measured in 2002. Control definitions are reported in Table 2 notes. Standard errors clustered by region are reported in parentheses. Stars indicate statistical significance at $1 \%(* * *), 5 \%(* *)$, and $10 \%(*)$. 